\title{
Strategic Business Development of Polosan Mas Ibing with the Business Model Canvas Approach
}

\author{
*Supriandi ${ }^{1}$, Yusuf Iskandar ${ }^{2}$ \\ ${ }^{I}$ Management Study Program, Faculty of Business and Humanities, Nusa Putra University, Indonesia \\ ${ }^{I}$ Management Study Program, Faculty of Business and Humanities, Nusa Putra University, Indonesia \\ *Corresponding author. Email: supriandi_mn18@nusaputra.ac.id
}

\begin{abstract}
Business development in Indonesia has experienced a relatively rapid increase, strategies in business must be carried out to achieve the level of success now and in the future. The need for a business strategy in line with business progress is a must. It is expected to provide business advantages so that the products produced can compete with products that are currently circulating. In the last few decades, the fashion industry has experienced rapid development. Small and Medium Enterprises are a field for the economy because they have a role in expanding employment opportunities, forming Gross Domestic Product (GDP), and providing productive economic activities to low-income communities. Although affected by Covid-19, the social entrepreneurship sector can still survive compared to other sectors. Polosan Mas Ibing still has problems with alternative strategies and priorities in his business journey. Polosan Mas Ibing is still relatively slow in its development, this can be related to internal and external aspects, in the establishment of this business, it is still stagnant, or no changes have been added, not a long-term strategy short and long term, as well as the use of the suitable business model. So, we need a business model; a business model is a way to formulate a strategy to stay competitive and compete with the business model, namely by a combination of SWOT, BMC, and QSPM analysis. This research uses qualitative research methods; qualitative research is a form of research based on naturally examining the object's condition of research. Polosan Mas Ibing's current business condition is in the Hold \& Maintain. In that position, the company should carry out intensive strategies where market penetration, market development, product development, and product development can assist the company in developing its business. SWOT analysis of BMC elements in Polosan Mas Ibing resulted in eight alternative strategies, namely expanding market segments, optimizing marketing partners and finding potential partners, optimizing marketing and promotions to get new customers, optimizing product production and Distribution, optimizing human resources with IT education, conducting the latest innovations to add products and develop existing products, optimize existing e-commerce as a place to maximize sales and increase company income through online marketing activities. Quantitative Strategic Planning Matrix (QSPM) priority alternative strategy with the highest rating is to carry out the latest innovations to add new products and develop products with a TAS value of 8.08 .
\end{abstract}

Keywords: Strategic, BMC, SWOT, QSPM.

\section{INTRODUCTION}

Business development in Indonesia has experienced a relatively rapid increase [1]. Many businesses are being founded today; of course, through proper planning and strategy for businesses to create, deliver and capture value, they can make companies highly competitive [2]. In fulfilling their daily needs, Indonesian people no longer only rely on opportunities as employees because the number of the workforce is much larger than employment [3]. Strategy in business is essential for efforts to achieve success now and in the future, of course, because environmental conditions continue to change appropriately, requiring business leaders to quickly understand how to deal with developments and when to adjust and implement changes in a strategy [4]. The need for a business strategy and the functional progress of the business is a demand. 
It is expected to provide business advantages so that the products produced can compete with products that are currently circulating [5]. Entrepreneurs are required to compete with all the risks of uncertainty to survive and compete and be able to accommodate technological developments [6].

The development of technology is increasingly rapid, so business competition in this era of globalization is very tight, such as in the fashion industry [7]. The clothing (fashion) industry will continue to develop and innovate. This is something that every individual will always need because it is the primary human consumption [8]. Individuals have three primary needs: clothing, food, and shelter [9].

Indonesia has millions of business actors in the small economic sector, namely SMEs [10]. Small and Medium Enterprises (SMEs) is a term that refers to the type of small business that has a net worth of at most Rp. 200,000,000,- excluding land and buildings for business premises and independent businesses (Law No. 1995). Small and Medium Enterprises (SMEs) are a driving force for the economy because they have a role in expanding employment opportunities, forming Gross Domestic Product (GDP), and providing activities productive economy to low-income people [11].

The city of Bandung has long been known as a fashion mecca in Indonesia. Stated that the City of Bandung, in developing the fashion industry is quite successful, rapidly seen by the number of Factory Outlets (FO), Clothing Company (CC), and Distribution Stores (Distro) which have become the identity and icon of the City of Bandung [12]. Like the city of Bandung, Sukabumi has the selling power of the fashion industry. Currently, the fashion in the Sukabumi area is quite good and very developed, especially with an increasingly modern era. It can be seen with the distributions and outlets that sell fashion products with different styles and models [13]. The event of a local product brand is also an annual agenda that is highly awaited by consumers, such as JakCloth, Indie Clothing Expo, KICKFEST, Clothing which is an event that is more identical with local fashion products [14].

One of the SME businesses that are currently running and developing is "Polosan Mas Ibing" which is a pioneering business for a student, in this case, the author, the establishment of this business saw a business opportunity for the fashion industry in Sukabumi, this business sells plain t-shirts for everyday activities. T-shirts are an inseparable part of the human lifestyle on body tops; casual and straightforward models will feel comfortable in the community in accompanying human mobility in their daily lives at home and even in leisure activities [15]. In the course of his business, Polosan Mas Ibing, which has been running with his characteristics and looks different, is still relatively slow in its development, this can be related to internal and external aspects, in the establishment of this business until now it is still stagnant, or there is no change plus not paying attention short-term and long-term business strategies, as well as the use of appropriate business models. Creative industry players such as fashion often have obstacles in introducing local brands influenced internally and externally [16].

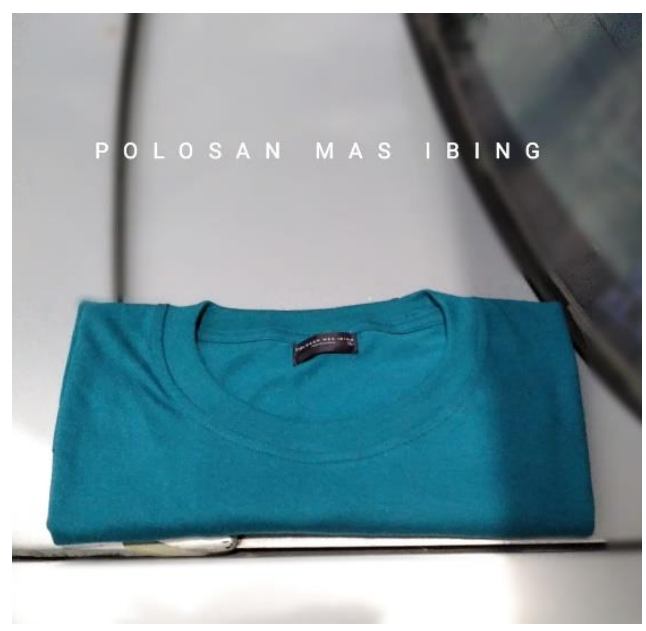

Figure 1. Product Polosan Mas Ibing

The core of the business model is the method used by a company formulated by management to generate income and profits for the business environment that will be carried out and faced, understanding the character of the organization and the sustainability of the company, namely operations [18]. It is said by [17] to achieve effectiveness by assessing the integrity of all business models, namely by combining analysis of strengths, weaknesses, opportunities, and threats (SWOT) with the Business Model Canvas (BMC). Then the business model will help the company with future business strategies.

One of the approach tools that can be used is the Business Model Canvas (BMC), which describes the business model as an alternative to creating a more competitive strategy [19]. Business Model Canvas is an overview, visualization, assessing, and changing a company's business model [20]. 


\section{LITERATURE REVIEW}

\subsection{Business Strategy}

To achieve the business's goals, strategy can be a tool that acts as an accelerator and dynamist so that the business's goals can be achieved effectively and efficiently. Strategy is believed to be a tool to achieve business goals [7]. Strategy is a comprehensive and integrated unified plan designed to ensure that the main goals of the organization or business can be achieved through proper implementation [21]. Furthermore, in the above definition, according to [22], strategic management focuses on efforts to integrate management, marketing, finance or accounting, production or operations, research and development, and computer information systems to achieve organizational success.

\subsection{Fashion Definition}

Fashion is something that a person wears, clothing and accessories. Definition of Fashion (Clothing) is very loved and a favorite of every human being, both male and female, because fashion itself can give an identity to others about the way we style and give confidence [23]. Since ancient times fashion has had a flexible development, as evidenced by developments in various fields, namely technology, science, and art [24].

\subsection{Fashion and T-Shirts}

Products often encountered in society as clothes that are used are t-shirts, not only for men but also for many women who wear them in everyday life. Consumers, especially students, prefer casual styles such as plain t-shirts, semi-formal shirts, flannel shirts, and t-shirts. Fashionable appearance on campus is a necessity that is difficult to bargain [25].

\subsection{Vision and Mission}

The definition of vision is a statement that contains clear directions about what the company will do in the future [26]. Vision is a series of sentences that state the ideals or dreams of an organization or company to be achieved in the future [27]. The following are the characteristics of a practical vision according to [3]: Interesting (Desirable), Can be imagined (Imagible), Realistic and achievable (Feasible), Easy to understand (Communicable), Responsive and aspirational to the environment (Flexible), \& Clear (Focused).
The definition of mission is a sentence description that contains the purpose and reasons for the existence of an organization that includes what is provided by the company/organization to the community, in the form of products and services. Mission can be used as a guide in today's business world [28]. The mission generally provides a clearer picture than the vision. Generally, the mission has four requirements, namely: measurable, understandable, relevant (relevant), and reliable (reliable) [29].

\subsection{SWOT Analysis}

SWOT analysis will compare internal factors of strengths and weaknesses, with external factors namely opportunities and threats [30]. Then, the internal factors will be input into a matrix called the internal strategy factor matrix (IFE). Internal Factor Evaluation, the IFE matrix, is used to determine the company's internal factors related to the company's strengths and weaknesses, consisting of aspects of human resources, marketing, production and operations, finance and accounting, and information systems. While external factors are inputted into the external strategy factor matrix, namely (EFE) External Factor Evaluation, the EFE Matrix is used to evaluate the company's external factors.

\subsection{Business Model Canvas}

Business Model Canvas (BMC) is an overview, visualization, assessing, and changing a company's business model [20]. The research of [31] which provides the view that $\mathrm{BMC}$ is a business model that can be used to start a service or product (trade) business. The Business Model Canvas will help a company optimize its strengths and see an opportunity, while still implementing regular evaluations of emerging weaknesses. The purpose of the Business Model Canvas is to introduce a standard way of reviewing a business model that a company has run [20].

\subsection{Quantitative Strategic Planning Matrix (QSPM)}

According to [32], the Quantitative Strategic Planning Matrix or QSPM is a tool that helps enable strategy development by evaluating alternative strategies objectively based on previously identified important external and internal success factors. This technique objectively shows the external and internal factors of the strategy that have an impact and chooses the best [33]. The advantage of using QSPM is that strategies can be checked sequentially and simultaneously, and there is no limit on the number of strategies to be evaluated [34]. 


\section{METHODOLOGY}

This research entitled "The Mas Ibing Polosan Business Development Strategy with the Business Model Canvas Approach" uses qualitative research methods. With the title of approach, qualitative research methodology said that in this method step, the author must describe the object of research, phenomena in the object of research, or social settings, which will later be poured into narrative writing [35]. This study analyzes the collaboration of internal factors (strengths, weaknesses) with external factors (opportunities, threats). SWOT is then identified into nine elements of BMC and will be the design of future business models [36]. The data used are primary and secondary data.

\subsection{Subject and Object}

The subject of this research is the CEO / Leader of Polosan Mas Ibing, and the object of the research is the UKM Polosan Mas Ibing, who is domiciled in Sukabumi Regency, West Java Province. The ease of obtaining data, observations, and interviews is the basis for selecting the object of this research. This study took eight months.

\subsection{Research Analysis Unit}

The design of the business model canvas for Polosan Mas Ibing refers to the book Business Model Generation written by [17] in filling out and adapted to aspects of Polosan Mas Ibing's business. In the early stages of the research, the authors made preparations by using swot analysis and identifying problems, and mapping the nine blocks that exist in the Business Model Canvas approach. The second stage is the process of collecting research data by conducting observations, interviews, and Documentation.

\subsection{Data Filtering Technique}

The data that has been obtained is then identified, sorted, elaborated, and grouped into nine elements of the approach according to the Business Model Canvas [18]. In the research, the data was obtained from the sources, selected using the purposive sampling technique. Where is defined as a situation in which an expert uses judgment when selecting respondents with a specific purpose in it [37].

\subsection{Method of Collecting Data}

1) Observation

Observation is a data collection technique and is carried out by conducting detailed and thorough research, and recording in a systematic way [38].
2) Interview

According to [39], interviewing is a process that will produce information and data by holding questions and answers.

3) Documentation

Documentation includes static (photo) and dynamic (video) capture or recording, based on [15].

\subsection{Data Analysis Technique}

In analyzing data, this study uses data analysis techniques in qualitative research so that a systematic process for searching and organizing interview transcripts, field notes, and other materials to find what is essential to report to others as a research finding includes data collection, data reduction, presenting data and drawing conclusions [35].

\subsection{Data Validity Technique}

In qualitative research, findings or data can be declared valid if there is no difference between what is reported by the researcher and what actually happened to the object under study [40].

\section{RESULT AND DISCUSSION}

\subsection{General Description of The Company}

Polosan Mas Ibing is one of the SMEs engaged in the fashion industry, established in 2020. Polosan Mas Ibing itself produces plain t-shirts that vary from one color to color combinations with raw materials that have been tested and passed the test process and are OEKO standard -TEX100 and BCI (better Coton international). The production of plain shirts from Polosan Mas Ibing is by consumer demand, wherein its business Polosan Mas Ibing provides ready-made products and custom products or requests according to consumer wishes. Polosan Mas Ibing is located in Lebak Nangka Village RT.04.01, Bojongasih Village, Parakansalak District, Sukabumi Regency, West Java Province.

\subsection{Company Vision, Mission, Goals}

\subsubsection{Company Vison Polosan Mas Ibing}

"Brand towards clothing strength with a focus on products, supply chain, employees, shops and communities, Polosan Mas Ibing from local will become global through business."

\subsubsection{Company Mission Perusahaan Polosan Mas Ibing}

"Polosan Mas Ibing will continue to provide casual clothes with fashionable, high quality and 
low prices compared to similar competitors. The resulting product will be forwarded to anyone, anytime, and anywhere to be used. Focus on product quality and link production with marketing through the lowest prices. Provide a positive vibes environment for employees to achieve positive work results to go global."

\subsubsection{Company Goals Polosan Mas Ibing}

Companies that are established indeed have short, medium, and long-term goals. Polosan Mas Ibing himself has a long-term goal of becoming a business that is beneficial for every line of the economy and contributes to employment so that it becomes a business that has a significant impact on the surrounding environment, a large and beneficial environment for everyone, and becomes a big business, starting from products, supply chain, employees whose primary goal is to enter the international market. Even though the current Covid-
19 pandemic situation has had a tremendous impact on the fashion industry, such as rising raw material prices, scarce raw materials to a decrease in revenue and sales turnover, Polosan Mas Ibing is sure that he will find a bright spot in difficult circumstances so that sales return to normal. As well as other aspects.

\subsection{Identification of The Current Business Model of Polosan Mas Ibing}

The nine-element business model canvas (BMC) approach was adopted in the book written by [41]. This research focuses on the Polosan Mas Ibing company and then maps it in the BMC, consisting of customer segments, value propositions, channels, customer relationships, revenue streams, key resources, key activities, and cost structure. These nine elements serve as guidelines in this study, guided by interviews conducted by the author with informants.

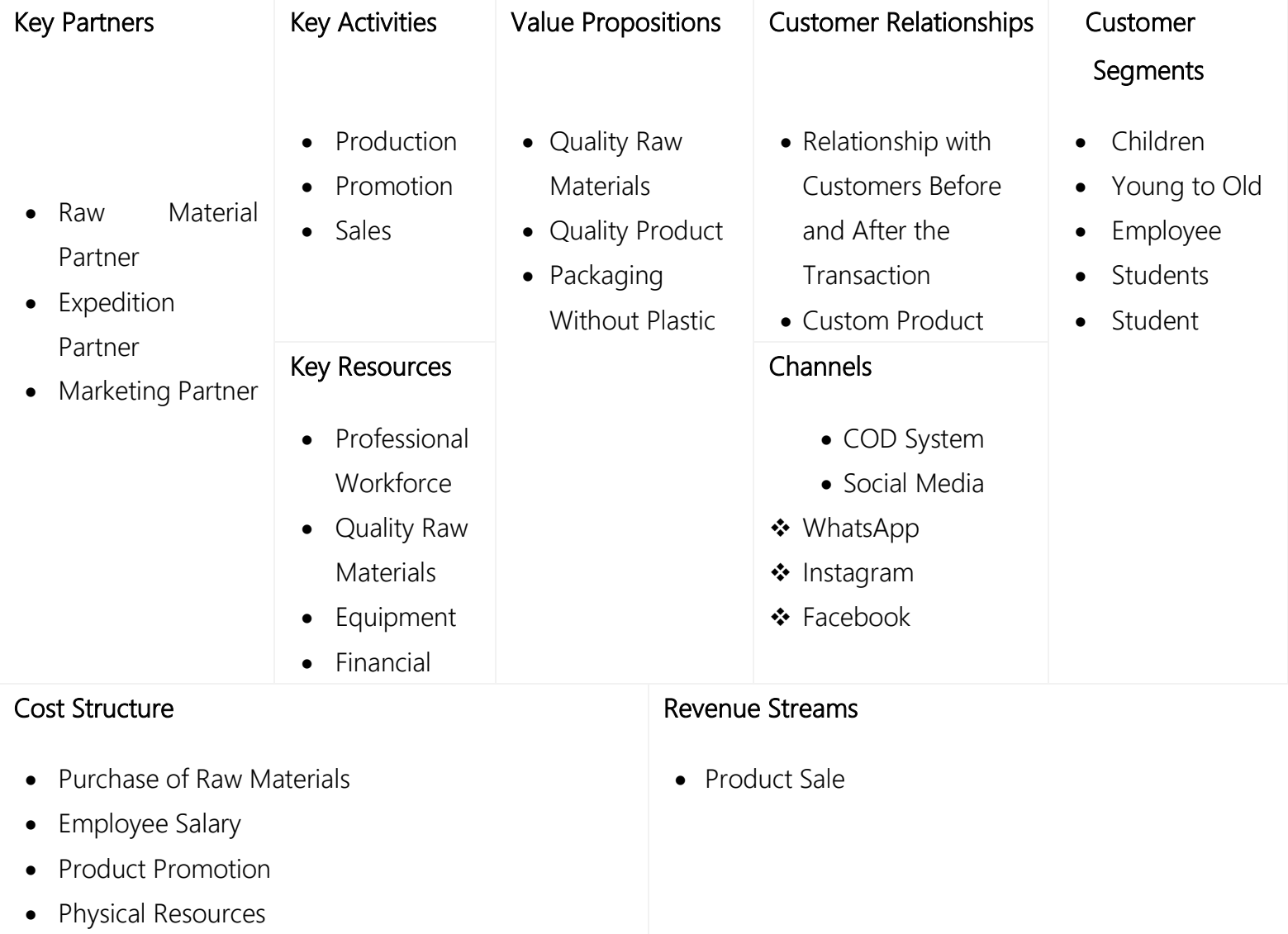

Figure 2. Current Business Model Canvas Polosan Mas Ibing Source: [20]

\subsection{Identification SWOT and BMC}

After identifying the BMC elements on Polosan Mas Ibing and having verified them with Polosan Mas Ibing, then evaluating the BMC with SWOT to evaluate and find out the internal and external companies of each BMC, the results of the evaluation will be used as an alternative strategy in formulating and formulating the latest business model at Polosan Mas Ibing. Provide the most effective way to reveal a BMC component in more detail to find new ways 
in a company's business model with a combination of SWOT and BMC [17].

Table 1. Identification of SWOT and BMC

\begin{tabular}{|c|c|c|c|c|}
\hline Element & Strength (S) & Weakness (W) & Opportunities (O) & Threats $(T)$ \\
\hline Customer Segment & $\begin{array}{l}\text { Provide custom } \\
\text { products } \\
\text { according to } \\
\text { consumer needs }\end{array}$ & $\begin{array}{l}\text { Companies find it } \\
\text { challenging to get } \\
\text { new customers }\end{array}$ & $\begin{array}{l}\text { The market is still } \\
\text { wide open, and } \\
\text { interest in online } \\
\text { shopping is } \\
\text { increasing }\end{array}$ & $\begin{array}{l}\text { Business } \\
\text { competition with } \\
\text { similar businesses }\end{array}$ \\
\hline Value Proposition & $\begin{array}{l}\text { Quality raw } \\
\text { materials with } \\
\text { OEKO-TEX } 100 \\
\text { and } \mathrm{BCl} \\
\text { standards } \\
\text { Environmentally } \\
\text { friendly products }\end{array}$ & $\begin{array}{l}\text { Do not have } \\
\text { products other than } \\
\text { plain t-shirts }\end{array}$ & $\begin{array}{l}\text { Build new } \\
\text { products and find } \\
\text { new customers } \\
\text { through online } \\
\text { marketing }\end{array}$ & $\begin{array}{l}\text { Raw material } \\
\text { prices have } \\
\text { increased }\end{array}$ \\
\hline Channels & $\begin{array}{l}\text { Distribution } \\
\text { according to } \\
\text { customer wishes, } \\
\text { implementing } \\
\text { the COD }\end{array}$ & $\begin{array}{l}\text { Promotion Is Not } \\
\text { Good }\end{array}$ & $\begin{array}{l}\text { Promotion is not } \\
\text { good Distribution } \\
\text { to all regions in } \\
\text { Indonesia }\end{array}$ & $\begin{array}{l}\text { Product damage } \\
\text { during } \\
\text { Distribution }\end{array}$ \\
\hline Customer Relationship & $\begin{array}{l}\text { Relationships } \\
\text { with customers } \\
\text { when ordering } \\
\text { and after, asking } \\
\text { for advice and } \\
\text { evaluation of } \\
\text { products } \\
\text { received }\end{array}$ & $\begin{array}{l}\text { Less familiar with } \\
\text { the company name }\end{array}$ & $\begin{array}{l}\text { Optimizing online } \\
\text { marketing }\end{array}$ & $\begin{array}{l}\text { Customers turn to } \\
\text { similar businesses }\end{array}$ \\
\hline Revenue Stream & $\begin{array}{l}\text { Customers have } \\
\text { different } \\
\text { payment } \\
\text { capabilities, } \\
\text { especially } \\
\text { custom products }\end{array}$ & $\begin{array}{l}\text { The company's } \\
\text { income is only from } \\
\text { product sales }\end{array}$ & $\begin{array}{l}\text { Increasing } \\
\text { company income } \\
\text { by entering the e- } \\
\text { commerce }\end{array}$ & $\begin{array}{l}\text { The Covid-19 } \\
\text { pandemic makes } \\
\text { consumers hold } \\
\text { back their money }\end{array}$ \\
\hline
\end{tabular}




\begin{tabular}{|c|c|c|c|c|}
\hline Key Resources & $\begin{array}{l}\text { Experienced } \\
\text { production } \\
\text { workforce }\end{array}$ & $\begin{array}{l}\text { Key resources are } \\
\text { easy to imitate, } \\
\text { human resources } \\
\text { that are owned are } \\
\text { not good at using } \\
\text { technology }\end{array}$ & $\begin{array}{l}\text { Optimizing } \\
\text { technological } \\
\text { developments }\end{array}$ & $\begin{array}{l}\text { Raw material } \\
\text { prices continue to } \\
\text { increase }\end{array}$ \\
\hline Key Activities & $\begin{array}{l}\text { Quality raw } \\
\text { materials with } \\
\text { OEKO-TEX } 100 \\
\text { and } \mathrm{BCl} \\
\text { standards }\end{array}$ & $\begin{array}{l}\text { Key resources are } \\
\text { easy to imitate } \\
\text { Do not have } \\
\text { products other than } \\
\text { plain t-shirts }\end{array}$ & $\begin{array}{l}\text { Build new } \\
\text { products and find } \\
\text { new customers } \\
\text { through online } \\
\text { marketing }\end{array}$ & $\begin{array}{l}\text { The price of raw } \\
\text { materials } \\
\text { continues to } \\
\text { increase }\end{array}$ \\
\hline Key Partnership & $\begin{array}{l}\text { Partnerships } \\
\text { help the } \\
\text { company's sales }\end{array}$ & $\begin{array}{l}\text { Do not have } \\
\text { partners from } \\
\text { outside the area }\end{array}$ & $\begin{array}{l}\text { Build potential } \\
\text { partners from } \\
\text { outside the area }\end{array}$ & $\begin{array}{l}\text { Partners join } \\
\text { similar businesses }\end{array}$ \\
\hline Cost Structure & $\begin{array}{l}\text { Stable product } \\
\text { sales }\end{array}$ & $\begin{array}{l}\text { Company capital } \\
\text { private capital }\end{array}$ & Increase sales & $\begin{array}{l}\text { Raw material } \\
\text { prices have } \\
\text { increased }\end{array}$ \\
\hline
\end{tabular}

\subsection{Strategic Formulation Stage}

The steps or stages of strategy formulation, there are three stages, namely the first entry stage, the second matching stage, and the third stage of decision making with matrix analysis of IFE, EFE SWOT, and QSPM [42].

Table 2. Result of the Evaluation Internal Factor

\subsection{The Result of The Evaluation of Internal Factors Polosan Mas Ibing}

Evaluation of internal process factors that determine the strengths and weaknesses that exist in the company. The process in determining is called the IFE method. The results received are in the form of weights obtained by multiplying the weights by the internal rating.

\begin{tabular}{|c|c|c|c|c|}
\hline No & Question & & & \\
\hline \multicolumn{2}{|c|}{ Internal Factor Strenght (Kekuatan) } & Bobot & Rating & Score \\
\hline 1 & Quality raw materials and products & 0,13 & 4 & 0,52 \\
\hline 2 & Eco-friendly packaging and affordable price & 0,13 & 3 & 0,39 \\
\hline 3 & Good relationship with customers and partnership & 0,13 & 4 & 0,52 \\
\hline
\end{tabular}




\begin{tabular}{|c|c|c|c|c|}
\hline 4 & Distribution is good and easy to find & 0,12 & 4 & 0,48 \\
\hline & & & & 1,91 \\
\hline No & Question & & & \\
\hline \multicolumn{5}{|c|}{ Internal Factor Weakness } \\
\hline 1 & $\begin{array}{l}\text { Customers are not well-segmented, and the company is having } \\
\text { a hard time getting new customers }\end{array}$ & 0,13 & 1 & 0,13 \\
\hline 2 & $\begin{array}{l}\text { Promotion is not attractive because the use of technology has } \\
\text { not been going well }\end{array}$ & 0,13 & 2 & 0,26 \\
\hline 3 & $\begin{array}{l}\text { Lack of innovation and don't have a product other than plain t- } \\
\text { shirts }\end{array}$ & 0,13 & 2 & 0,26 \\
\hline \multirow[t]{3}{*}{4} & $\begin{array}{l}\text { Internet marketing activities are not suitable, and the company } \\
\text { does not have IT, employees, for online marketing activities }\end{array}$ & 0,12 & 2 & 0,24 \\
\hline & & 1 & & 0,89 \\
\hline & Total IFE 2,80 & & & \\
\hline
\end{tabular}

Based on table 2, the results of data processing illustrate that the main strengths of Polosan Mas Ibing are two factors, namely raw materials and quality products, customer relationships, and good partnerships, which get a score of 0.52. Meanwhile, the current weakness of Polosan Mas Ibing is that the promotion is not attractive because the use of technology has not been going well, and the lack of innovation does not yet have a product other than plain t-shirts that get a score of 0.26. In the IFE matrix, the total internal score obtained by Polosan Mas Ibing is 2.80; this shows and can be interpreted that Polosan Mas Ibing can take advantage of existing strengths and overcome existing weaknesses.

\subsection{Result of The Evaluation of External Factors}

Evaluating external factors is a process to determine the main opportunities and main threats of the company. This process is carried out using EFE (External Factor's Evaluation). The results of EFE processing are in the form of scores, namely the multiplication between weights and external ratings.

Table 3. Result of the Evaluation External Factor

No Pertanyaan




\begin{tabular}{|c|c|c|c|c|}
\hline 2 & $\begin{array}{l}\text { The development of the fashion industry is increasing with the online system } \\
\text { because people are starting to love domestic products }\end{array}$ & 0,12 & 4 & 0,48 \\
\hline 3 & Build potential partners to help company sales & 0,12 & 3 & 0,36 \\
\hline 4 & $\begin{array}{l}\text { Plain t-shirts do not know trends, and social media promotions are getting } \\
\text { more exciting and faster }\end{array}$ & 0,12 & 4 & 0,48 \\
\hline & & & & 1,84 \\
\hline
\end{tabular}

No

Question

\begin{tabular}{|c|c|c|c|c|}
\hline \multicolumn{5}{|c|}{ External Factor Threats } \\
\hline 1 & $\begin{array}{l}\text { Prices of raw materials have increased and economic conditions are } \\
\text { unpredictable }\end{array}$ & 0,12 & 2 & 0,24 \\
\hline 2 & The number of similar businesses and many imported products & 0,13 & 2 & 0,26 \\
\hline 3 & The company's income is only from product sales & 0,13 & 2 & 0,26 \\
\hline \multirow[t]{2}{*}{4} & Rapid technological developments must continue to be followed & 0,13 & 1 & 0,13 \\
\hline & & 1 & & 0,89 \\
\hline
\end{tabular}

Total EFE 2,73

Based on the data processing results in table 3 , the total external score of Polosan Mas Ibing is 2.73. The foremost opportunity for Polosan Mas Ibing is that the market is still wide open due to rapid technological developments with a score of 0.52 . Meanwhile, the threats faced by Polosan Mas Ibing are the number of similar businesses and many imported products, the company's income is only from product sales, and rapid technological developments must continue to be followed by a score obtained of 0.26 .

\subsection{Result Matrix Internal and External (IE) Polosan Mas Ibing}

The IE matrix is a combination of the total score from the evaluation of internal and external factors. Developed the IE matrix to determine the condition of the company and describe the appropriate strategic alternatives [32]. Here is Mas Ibing's Polosan Matrix: 
Picture 3. IE Matrix Polosan Mas Ibing

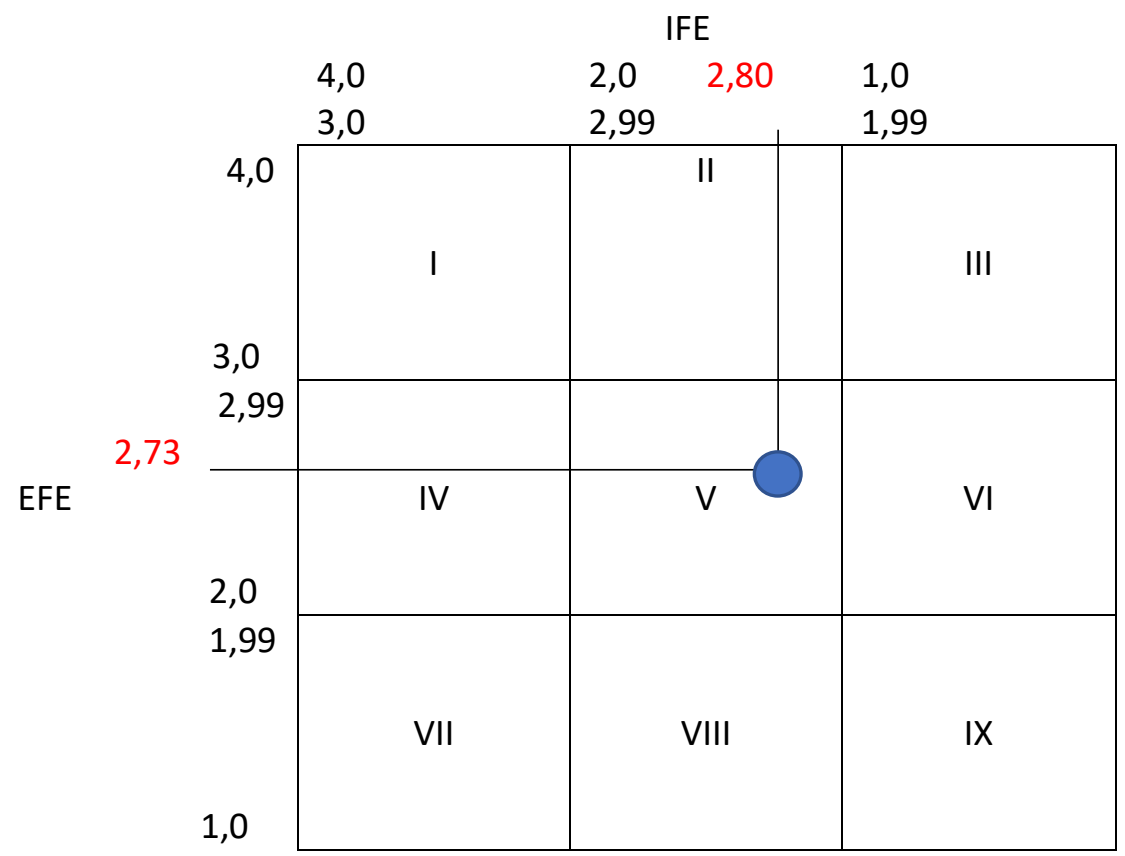

Polosan Mas Ibing's total IFE score is 2.80, and the total EFE score is 2.73. Based on the results of the IE matrix, Mas Ibing's Polosan condition is in division number $\mathrm{V}$. is the position of Polosan Mas Ibing in the stage of being maintained and maintained. Strategies that are appropriate for this area are market penetration strategies and product development. Polosan Mas Ibing should now be ready to develop business by maximizing existing strengths and opportunities, and improving and minimizing existing weaknesses and threats

\subsection{Result SWOT Matrix Polosan Mas Ibing}

This SWOT matrix is a formulation tool in determining strategic decisions to be taken based on logic to maximize strengths and opportunities, but besides that, it can minimize existing weaknesses and threats. The following is the compilation of Mas Ibing's Polosan SWOT matrix:

Table 5. SWOT Matrix Polosan Mas Ibing

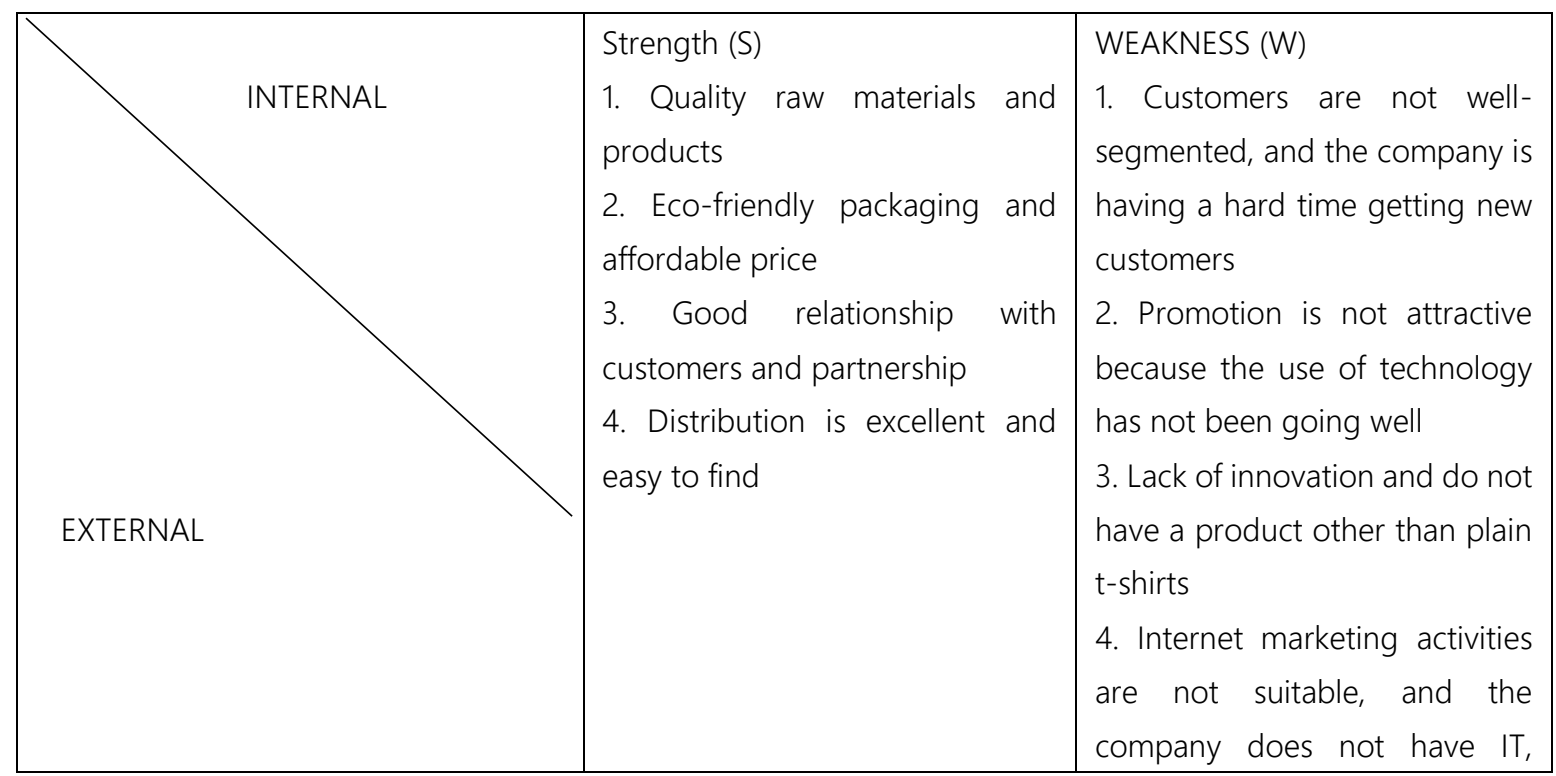




\begin{tabular}{|c|c|c|}
\hline & & $\begin{array}{l}\text { employees, for online marketing } \\
\text { activities }\end{array}$ \\
\hline $\begin{array}{l}\text { Opportunities (O) } \\
\text { 1. The market is still wide open due to } \\
\text { the rapid development of technology } \\
\text { 2. The development of the fashion } \\
\text { industry is increasing with the online } \\
\text { system because people are starting to } \\
\text { love domestic products } \\
\text { 3. Build potential partners to help } \\
\text { company sales } \\
\text { 4. Plain t-shirts do not know trends, } \\
\text { and social media promotions are } \\
\text { getting more exciting and faster }\end{array}$ & $\begin{array}{l}\text { Strategy S-O } \\
\text { 1. Expansion of market segments. } \\
\text { 2. Optimizing marketing partners } \\
\text { and finding potential partners. } \\
\text { 3. Optimizing marketing and } \\
\text { promotional activities to get new } \\
\text { customers. }\end{array}$ & $\begin{array}{l}\text { Strategi S-T } \\
\text { 1. Optimizing the production } \\
\text { and distribution of products }\end{array}$ \\
\hline $\begin{array}{l}\text { THREATS (T) } \\
\text { 1. Prices of raw materials have } \\
\text { increased, and economic conditions } \\
\text { are unpredictable } \\
\text { 2. The number of similar businesses } \\
\text { and many imported products } \\
\text { 3. The company's income is only from } \\
\text { product sales } \\
\text { 4. Rapid technological developments } \\
\text { must continue to be followed }\end{array}$ & $\begin{array}{l}\text { Strategi W-O } \\
\text { 1. Optimizing human resources } \\
\text { with IT education. } \\
\text { 2. Carry out the latest innovations } \\
\text { to add products and develop } \\
\text { existing products. }\end{array}$ & $\begin{array}{l}\text { Strategi W-T } \\
\text { 1. Optimizing existing e- } \\
\text { commerce as a place to } \\
\text { maximize sales. } \\
\text { 2. Increase the company's } \\
\text { income through online } \\
\text { marketing activities. }\end{array}$ \\
\hline
\end{tabular}

The Following strategic are generated From the Matrix:

Table 6. Result of Alternative Strategies

\begin{tabular}{|l|}
\hline \multicolumn{1}{|c|}{ Alternative Strategies } \\
\hline AS1 $=$ Market Segment Expansion \\
\hline AS2 = Optimizing marketing partners and looking for potential partners \\
\hline AS3 = Optimizing marketing and promotional activities to get new customers. \\
\hline AS4=Optimizing product production and Distribution. \\
\hline
\end{tabular}




\begin{tabular}{|l|}
\hline AS5 $=$ Optimizing human resources with IT education \\
\hline AS6=Conduct the latest innovations to add products and develop existing products. \\
\hline AS7=Optimizing existing e-commerce as a platform to maximize sales. \\
\hline AS8=Increase company revenue through online marketing activities. \\
\hline
\end{tabular}

\subsection{The Decision Stage at Polosan Mas Ibing}

The matrix used in this decision stage is the QSPM (Quantitative Strategic Planning Matrix) matrix. This technique will show which alternative strategy is the best and most relevant for a company to choose. QSPM.

\subsection{QSPM Matrix Assessment Results Polosan Mas Ibing}

The QSPM matrix is the final stage in the strategy formulation analysis that provides options for the company's most suitable priority strategy to be carried out.

Table 7. Results of QSPM. Matrix Assessment

\begin{tabular}{|c|l|c|c|}
\hline No & \multicolumn{1}{|c|}{ Strategies } & Value & Rating \\
\hline 1 & Market Segment Expansion & 6,07 & VI \\
\hline 2 & Optimizing marketing partners and looking for potential partners. & 4,67 & VIII \\
\hline 3 & Optimizing marketing and promotional activities to get new customers & 6,31 & V VII \\
\hline 4 & Optimizing product production and distribution. & 6,43 & IV \\
\hline 5 & Optimizing product production and distribution. & 8,08 & I \\
\hline 6 & Conduct the latest innovations to add products and develop existing products. & 7,45 & II \\
\hline 7 & Optimizing existing e-commerce as a platform to maximize sales. & 6,81 & III \\
\hline 8 & Increase company revenue through online marketing activities. & & VII \\
\hline
\end{tabular}

Formulation based on calculations carried out with like values and TAS values, AS values provide strategic choices related to the factors in the priority strategy, which will later be used as suitable strategies for the company. The results of table 6 show that the primary priority strategy immediately carried out by Polosan Mas Ibing is to carry out the latest innovations to add products and develop existing products with a TAS value of 8.08. Polosan Mas Ibing currently only has plain t-shirts. This is very relevant to the current state of the company.
The strategies can be seen above where what is most needed by this company is intensive where the results of the strategy are related to market penetration, product development, and product development so that it can be used as an assessment that this research is intentional, not evaluation. This is also by the resulting IE matrix that Polosan Mas Ibing is in a Hold \& Maintain position. Namely, the appropriate strategy is that the company should carry out intensive strategies where market penetration, market development, product development, and product development can assist the company in developing its business [32]. 


\subsection{Recomended Model Bisnis Update Polosan Mas Ibing}

Key Partners

Key Activities

Value Propositions

Customer Relationships

Customer

Segments

- Production

- Raw Material Partner

- Expedition Partners

- Offline Sales Partner

- Online Marketing Partner

- Screen Printing Partners
- New Products

- Innovation

- Sales

- Distribution

- Online Marketing
- Quality Products

- Environmental ly Friendly Packaging

- Custom Products

Key Resources

Channels

- Offline COD

- Professional

- T-shirts Supplier

- Social Media

Workforce

- Quality Raw

Materials

- Sales

- Production

Facilities

- Financial

\section{Cost Structure}

- Raw Material Cost Biaya Bahan Baku

- Production Cost

- Employee Salary Cost

- Promotion Fee

- Maintenance Cost
- Young to Old People

- Children Through Social Media and E-

- Students and Commerce

- Products can be requested according Students

- Employee

- Community

- Screen

- Discussion with customers before Entrepreneur and after ordering

- Out-OfTown Costumers
o Facebook
- Instagram
- WhatsApp
- TikTok
- E-Comerse
- Bukalapak
- Shopee
- Lazada
- Tokopedia
- Event Fashion

Revenue Streams

- Direct Product Sales

- Online Products Sales

- Additional Owner's Personal Capital

- Investor Capital Increase

- Event Fashion

Figure 3. Business Model Canvas Update Polosan Mas Ibing 


\section{AUTHORS' CONTRIBUTIONS}

Based on the research conducted, the following conclusions were found in answering the formulation of the existing problems:

The results of identifying the nine elements of $\mathrm{BMC}$ are beneficial in understanding, analyzing, and predicting activities that should be evaluated and continue to be developed. Polos Mas Ibing's current business condition is in Hold \& Maintain. In that position, the company should carry out intensive strategies where market penetration, market development, product development, and product development can assist the company in developing its business.

The results obtained in the SWOT analysis of the BMC elements in Polosan Mas Ibing resulted in eight alternative strategies, namely expanding market segments, optimizing marketing partners and finding potential partners, optimizing marketing and promotions to get new consumers, optimizing product production and Distribution, optimizing human resources by IT education, carrying out the latest innovations to add products and developing existing products, optimizing existing e-commerce as a forum to maximize sales and increase company income through online marketing activities. Based on the Quantitative Strategic Planning Matrix (QSPM) results, the alternative priority strategy with the highest rating is to carry out the latest innovations to add new products and develop products with a TAS value of 8.08 .

\section{ACKNOWLEDGMENTS}

The advice given by the author to Polosan Mas Ibing is to improve the current business model immediately, especially to evaluate the weaknesses that have been on the company's side and to focus on optimizing and maximizing the strengths that are currently owned and innovative in seeing current opportunities. There is something that will really benefit Polosan Mas Ibing. The results of the BMC in this study can be used as a strategy used by Polosan Mas Ibing in the future.

\section{REFERENCES}

[1] H. B. Sanjaya, D. R. Ruslan, S. R. Sundari, M. A. Hakim, and M. B. Alexandri, "Analisis peluang bisnis jasa fotografi "garis photography" dengan business model canvas dan analisis swot," Kinerja, vol. 17, no. 2, pp. 202-207, 2020, [Online]. Available: http://journal.feb.unmul.ac.id/index.php/KINE RJA/article/view/7429.

[2] N. N. Rizki, "Perancangan Model Bisnis Alumnibisa . Com Dengan Pendekatan Business Model Canvas ( Bmc ) Design of
Business Model Alumnibisa . Com," vol. 7, no. 1, pp. 1846-1853, 2020.

[3] Y. J. Natawigena, "Perencanaan bisnis fashion j'art skripsi,” pp. 1-3, 2016.

[4] A. Agostini, "Differences in business model innovation, a challenges perspective [disertasi]," Halmstad Halmstad Univ. Coll., 2014.

[5] N. Kuswardhani, R. Agustian, and M. L. Plus, "Strategi Pengembangan Bisnis 'Cofresh'(Coffee Fresh) Dengan Metode Bussines Model Canvas (BMC) dan QSPM (Quantitative Strategic Planning Matrix)," Agroindustrial Technol. J., vol. 4, no. 2, pp. 167-181, 2021.

[6] R. Rosmiati, D. T. S. Junias, and M. Munawar, "Sikap, motivasi, dan minat berwirausaha mahasiswa," J. Manaj. Dan Kewirausahaan (Journal Manag. Entrep., vol. 17, no. 1, pp. 21-30, 2015.

[7] F. Wijaya, "Formulasi Perancangan Strategi Pengembangan Usaha Menggunakan Analisis SWOT dan Business Model Canvas," J. Ilmu Manaj. Dan Bisnis, vol. 10, no. 2, pp. 205-212, 2019, doi: 10.17509/jimb.v10i2.15308.

[8] S. Mediana et al., "Perancangan Aplikasi ECommerce Untuk Meningkatkan Sarana Pemasaran Dan Penjualan Kaos Oblong ( Studi Kasus : Diponegoro Kaos Oblong ) Designing E-Commerce Application To Improve the Marketing Means and Sales of T-Shirts ( Case Study of Diponegoro Kaos Ob," vol. 7, no. 2, pp. 5616-5629, 2020.

[9] Y. Albana and I. Hasbi, “Analisis Model Bisnis Pada Geoff Max Dengan Menggunakan Pendekatan Business Model Canvas," eProceedings ..., vol. 7, no. 1, pp. 1125-1135, 2020, [Online]. Available: https://openlibrarypublications.telkomuniversi ty.ac.id/index.php/management/article/view/1 1610.

[10] A. Fahriyah and R. Yoseph, "Keunggulan Kompetitif Spesial sebagai Strategi Keberlanjutan UKM di Era New Normal," in Prosiding Seminar STIAMI, 2020, vol. 7, no. 2, pp. 104-110.

[11] Y. Iskandar, N. Zulbainarni, and S. Jahroh, "Pengaruh Karakteristik Usaha dan Wirausaha Terhadap Kinerja UMKM Industri Pengolahan Perikanan di Kabupaten Sukabumi," $J$. REKOMEN (Riset Ekon. Manajemen), vol. 4, no. 1 , pp. 1-12, 2020.

[12] E. A. Rizky Putra Ptama, "Analisis Model Bisnis Dengan Pendekatan Busnises Model Canvas (Studi Kaus MxD0," J. Chem. Inf. 
Model., vol. 53, no. 9, pp. 1689-1699, 2013.

[13] Rayyisa, “Современные Достижения Клинической Патофизиологии В Изучении Патогенеза Сахарного Диабета 1-Го И 2-Го Типа У Человека," Международный Эндокринологический Журнал, vol. 15, no. 6, pp. 310-320, 2019.

[14] C. Irna, V. Tafeni, A. Bisnis, and F. Komunikasi, "Analisis Event Marketing dan keputusan pembelian produk fashion lokal di kalangan pengunjung KICKEST Bandung," vol. 6, no. 2, pp. 97-117, 2020.

[15] M. S. Jasmail, A. A. Said, and Aswar, "T-Shirt Screen Printing Tutorial Design Manually Perancangan Tutorial Baju Kaos Secara Manual," 2018.

[16] N. P. Diantanti, S. Sunaryo, and M. Rahayu, "Perbandingan Penggunaan Local-Name Brand Dan Foreign-Name Brand Pada Produk Fashion Di Kota Malang," J. Bisnis dan Manaj., vol. 5, no. 1, pp. 92-101, 2018, doi: 10.26905/jbm.v5i1.2319.

[17] A. Osterwalder and Y. Pigneur, Business model generation: a handbook for visionaries, game changers, and challengers. John Wiley \& Sons, 2010.

[18] Kadir, "Analisis model bisnis bank mumalat dengan pendekatan,” pp. 40-50, 2021.

[19] E. Solihah, A. V. S. Hubeis, and A. Maulana, "Analisis model bisnis pada KNM fish farm dengan pendekatan business model canvas (BMC)," J. Sos. Ekon. Kelaut. dan Perikan., vol. 9, no. 2, 2014.

[20] A. Osterwalder and Y. Pigneur, "Designing business models and similar strategic objects: the contribution of IS," J. Assoc. Inf. Syst., vol. 14, no. 5, p. 3, 2012.

[21] M. E. David, F. R. David, and F. R. David, "The quantitative strategic planning matrix: a new marketing tool," J. Strateg. Mark., vol. 25, no. 4, pp. 342-352, 2017.

[22] F. David and F. R. David, Strategic management: A competitive advantage approach, concepts and cases. PearsonPrentice Hall Florence, 2016.

[23] D. A. Handayani, "Feasibility Analysis of Business 'Amalia Boutique'Ptwarna Warni Amalia As Muslimah Fashionin South Jakarta," JRMSI - J. Ris. Manaj. Sains Indones., vol. 7, no. 1, pp. 41-55, 2016, doi: 10.21009/jrmsi.007.1.03.

[24] P. D. Caraen, D. Yulistiana, and M. Psdm, "Deco Dengan Dunia Fashion," vol. 09, no. November, 2020.
[25] P. Prijana, "Internet Dan Gaya Fashion Mahasiswa," J. Kaji. Inf. dan Perpust., vol. 3, no. 2, p. 283, 2015, doi: 10.24198/jkip.v3i2.11590.

[26] A. Maulidi, S. Syamswisna, E. Daningsih, E. Ariyati, and R. Marlina, "Pengukuran Tingkat Pemahaman Mahasiswa Terhadap Visi Misi Program Studi Pendidikan Biologi Fkip Untan," BIO-PEDAGOGI, vol. 7, no. 2, pp. 91-95, 2018.

[27] A. Kibtiyah, "Hubungan Integritas Dan Loyalitas Karyawan Dengan Visi Misi Perusahaan (Studi Kasus Pada PT. Bank Central Asia, Tbk)," EDUKA J. Pendidikan, Huk. dan Bisnis, vol. 2, no. 2, pp. 92-110, 2016.

[28] Y. Gunawan Wibisono, "Kajian Yuridis Perjanjian Jual Beli Tenaga Listrik Yang Dilakukan Antara PT. PLN (PERSERO) Dengan Pelanggan.” Program Pasca Sarjana Universitas Diponegoro, 2006.

[29] M. J. Pranata and F. Idayati, "Penarapan Balanced Scorecard Dalam Pencapaian Visi Dan Misi Pada Sma Ipiems Surabaya," J. Ilmu dan Ris. Akunt., vol. 4, no. 2, 2015.

[30] A. N. Kumalasari, "Perencanaan Strategi Promosi Melalui Analisis SWOT Pada Bisnis Delicy," PERFORMAJurnal Manaj. dan StartUp Bisnis, vol. 1, no. 2, pp. 225-234, 2016.

[31] A. Suarni, F. Adzim, M. N. Abdi, and A. A. Adiningrat, "Training Bisnis Model Canvas (BMC) Bagi Petani Buah Naga Masa Pandemi Covid-19 Desa Caramming Bulukumba," J. Abmas Negeri, vol. 1, no. 1, pp. 11-19, 2020, doi: 10.36590/jagri.v1i1.88.

[32] M. E. David, F. R. David, and F. R. David, "The Quantitative Strategic Planning Matrix (QSPM) applied to a retail computer store," Coast. Bus. J., vol. 8, no. 1, pp. 42-52, 2009.

[33] R. F. Hasanah, Strategi Pengembangan Usaha Susu Sapi Perah dengan Pendekatan Business Model Canvas. 2020.

[34] H. O. Zulkarnaen and S. Sutopo, "Analisis Strategi Pemasaran Pada Usaha Kecil Menengah (UKM) Makanan Ringan (Studi Penelitian UKM Snack Barokah di Solo)." Fakultas Ekonomika dan Bisnis, 2013.

[35] A. Anggito and J. Setiawan, Metodologi penelitian kualitatif. CV Jejak (Jejak Publisher), 2018.

[36] R. M. Azhar, O. Suparno, and S. Djohar, "Pengembangan Model Bisnis pada Lokawisata Baturaden Menggunakan Business Model Canvas," Manaj. IKM J. Manaj. 
Pengemb. Ind. Kecil Menengah, vol. 12, no. 2, p. 137, 2018, doi: 10.29244/mikm.12.2.137144.

[37] M. Rahardjo, "Triangulasi dalam penelitian kualitatif," 2010.

[38] A. Tanzeh and S. Arikunto, "Metode Penelitian Metode Penelitian," Metod. Penelit., pp. 2234, 2014.

[39] S. Siregar, "Statistik Parametrik Untuk Penelitian," 2017.

[40] T. Soendari, "Pengujian keabsahan data penelitian kualitatif," Bandung Univ. Pendidik. Indones., 2001.
[41] A. Osterwalder, Y. Pigneur, G. Bernarda, and A. Smith, Value proposition design: How to create products and services customers want. John Wiley \& Sons, 2014.

[42] M. E. David, F. R. David, F. R. David, M. E. David, F. R. David, and F. R. David, "The quantitative strategic planning matrix : a new marketing tool," vol. 4488, no. April, 2016, doi: 10.1080/0965254X.2016.1148763. 